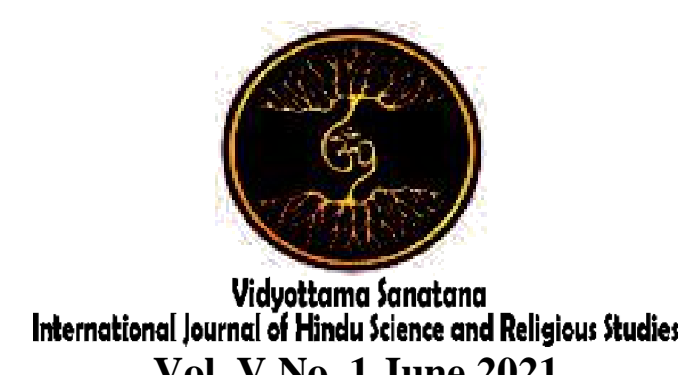

\title{
BUILDING RELIGIOUS INCLUSIVE BEHAVIOR AMONG STUDENTS
}

\author{
By: \\ Hermawan Winditya ${ }^{1}$, Ida Bagus Gde Yudha Triguna ${ }^{2}$, I Wayan Budi Utama ${ }^{3}$ \\ ${ }^{1}$ Character Building Development Center, \\ Bina Nusantara University, \\ Jakarta, Indonesia \\ ${ }^{1,2}$ Faculty of Religion and Culture \\ Indonesian Hindu University \\ winditya1975@gmail.com ${ }^{1}$, ajiktriguna@unhi.ac.id ${ }^{2}$, budiutama904@gmail.com $^{3}$
}

\begin{tabular}{l|l|l} 
Received: March 11, 2021 & Accepted: Juni 30, 2021 & Published: June 30, 2021
\end{tabular}

\begin{abstract}
The purpose of this study is to know why the students of Bina Nusantara University have inclusive religious character. This study used qualitative method by phenomenon approach. Various data sources such as data from focus group discussions (FGD), participant observation, and documents. This descriptive analysis technique is used to describe how learning can behave inclusively in religious education and its development patterns. Meanwhile, descriptive analysis techniques are used to describe field findings, make observations, interpret, and carry out the final analysis. The conclusions are (1) inclusive religious behavior in Binus has been implemented well by Binus students by building harmonious relations between students in the life of the academic community in Binus. They can get along well and can build together, both inside and outside the classroom. Harmony also occurs in relations with the wider community, which is manifested in the social activities of students, who are involved in UMKM activities and student associations at Binus. (2) the inclusion of inclusive student religious behavior by Binus has been well structured and planned through a learning process, an assessment system, and technical activities that are conducive to the plural reality of Indonesian society by building self-management and teamwork skills. There are some implications for the life of Bina Nusantara University, Jakarta. First, the relations between students of different religions in the classroom are getting tighter. Second, creating a family atmosphere between students in the organization. Third, the lecture atmosphere in the classroom is very conducive. Fourth, Binus' closeness to the surrounding community. Fifth, the brotherhood of the Binus academic community is getting tighter. Sixth, Binus' achievement enhancement.
\end{abstract}

Keywords: Religious inclusive behavior, Process of forming inclusive religious behavior, Implications of inclusive religious behavior. 


\section{I.}

\section{INTRODUCTION}

In the last few decades, religious education in Indonesia has faced serious problems. The existence of religious education subjects at all levels of education does not guarantee the realization of peace and harmony between religious believers. Religion increasingly shows a paradoxical face, namely that on the one hand it becomes a source of human value in living life, preaching peace, morality, brotherhood, social piety by acknowledging the existence of God as an absolute. However, on the other hand, in the name of religion, humans can behave ruthlessly, full of hatred, leading to massacres, mass murder, and the elimination of human values according Utama (2018: 86).

The existence of many facts that showed the strength of exclusivism in religion in the community and in the campus environment in particular is an indication that religion has failed to play its role as a peacemaker (problem solver) for the issue of SARA (Suku/ethnic, Agama/Religion, Ras/Race, Antar-golongan berbeda/Differentiation level in the society) as said by (Maksum, 2011: 68). This fact is thought to be closely related to exclusive religious learning. As a result, it results in acts of mutual disbelief, blaming other religions, apostasy from each other, and the like. In fact, it is not uncommon for the presence of sects (and even other religions) to be considered a threat. As a result, the seeds of conflict continue to be planted in individuals. More than that, an exclusive attitude can trigger violence in the name of religion both within the wider community and within the campus environment. Religion appears to be the face of violence and often causes many casualties. According Susanto (2006: 44-47), religion is often used as a tool of justification for acts of violence by certain groups, and even to negate different groups (Utama, 2018: 107).

According to Suhadi (2013: 66-69), students who only learn about their own religion are exclusively dogmatic, will find it difficult to admit the existence of followers of other religions that are different from them. The inability of students to accept different religions will lead to stereotypes towards other groups. If this happens, it will become a serious problem related to respect for differences in the context of nation and society. Religious education like this has the potential to produce students who only have faith in their religious group. This kind of religious teaching will further strengthen religion-centric behavior, meaning that only the social and religious groups are considered the best, while other religious groups are considered bad.

According to Bahari (2010), the most dominant variable that has a direct effect on student religious tolerance in tertiary institutions is the educational environment in the family, school, and community. According to Lukman (2011) expository learning tends to be teacher-centered. So, according to him, in order to improve the quality of education and learning, it is necessary to develop a cooperative script model in interfaith tolerance education through religious learning. The aim is for students to know, understand, appreciate, and be tolerant among religious believers. The program contains teachings about respecting other people of different religions. The implementation process begins with making a syllabus, making lesson plans, implementing learning in class and outside the classroom using a cooperative script model, and conducting evaluations by conducting pre-test and post-test, and assignments. This model can be used as a model of quality religious learning and has practical implications for the benefits of religious teachers, school principals, and students in developing a model for interreligious tolerance education.

According to Burhanuddin (2014), social construction takes place in a situation laden with interests. For constructivism, reality (news) is present in a subjective state. Reality is created through the constructs, viewpoints and ideologies of journalists. In short, he said that humans construct the image of the world so that a text is seen as a construction of reality. Burhanudin concludes that the fast and wide circulation of information creates a social construction that takes place very quickly and widely. This causes the constructed reality to also build mass opinion. That is why the news in the mass media has gone through a construction process before being shown to the public. Based on Berger and Luckmann's social construction theory, it is assumed that reality 
exists because of the continuous construction by individuals and is interpreted collectively. According to Sofyan (2011) there are several student perceptions about the meaning or concept of tolerance. The point is that in Islam there is no tolerance which is based on the respondent's understanding in his research. Sofyan concluded that a person is not allowed to embrace a religion other than Islam. This is one of the negative points of view that can trigger conflict between religious believers.

According to Fatah (2015), the PAI (Pendidikan Agama Islam) learning process with a case study at SMA Negeri 1 Kota Tangerang Selatan has proven to be able to build a culture of religious tolerance among students. The results of this study indicated several ways that can be done to instill the values of religious tolerance in students, namely student-centered learning approaches, learning methods based on religious tolerance, and extracurricular activities based on religious tolerance.

According to Darmani (2012), tolerant behavior needs to be practiced in various arts of life, namely family, school, community, nation and state life. This is important to do because tolerance can be used as an alternative bridge towards togetherness for the sake of national unity and unity itself.

According to Ghazali (2011) in line with the Islamic doctrine of religious harmony, it is necessary to develop PAI (Pendidikan Agama Islam) subjects with the insight of religious harmony. This is important because Islamic religious education must adapt to the community environment and be forward oriented. In addition, educational practice must be in accordance with the development of society and educational theories. On the other hand, educational theories must come from the perspective of life of the community concerned. Gazali (2011) offers a PAI (Islamic Religious Education) curriculum material format with the insight into religious harmony for public high schools. The results of this study are expected to help policy holders and education managers in developing a multi-religious and multicultural-based Islamic education curriculum.
According to Mahyuddin (2020) the role of the Ambon State Islamic Institute (IAIN) and the Ambon State Christian Institute (IAKN) in maintaining social tolerance and religious moderation is very significant. According to Mayudin, past religious conflicts have affected social tolerance and religious moderation in society. However, this threat can be resolved by the two religious higher education institutions by providing assistance and guidance to the wider community on the importance of maintaining harmony in diversity. In an effort to break the differences and antagonisms in society, Ambonese society is increasingly open. This means that it has changed to "harmony of life" and has come out of the world of "suspicion and hostility" even though the relationship between religious groups still has a strong potential for recurring social friction involving the two religious groups.

According to Abdul Aziz (2020) a pluralist educational method in Islamic religious education has positive implications for inter-religious relations at the Curub State Islamic Institute.

According to the result of the research that conducted by non-governmental organization, Setara Institute (2018), as many as $87.1 \%$ of respondents did not make religious differences in making friends an obstacle, and $67.4 \%$ of respondents could accept the fact of religious conversion. Based on this fact, it can be concluded that the social capital of tolerance for young people is very strong, but that social capital is not developed and is confined. This is because state administrators, including political parties, do not function properly.

Based on the exploration of the results of previous research as described above, it can be concluded that this research on the formation of inclusive religious behavior among students in Binus has very significant differences with previous research. The significance of the difference lies in the focus of the research study. In this case, the focus of the study is directed at how the learning of CB Religion in Binus in shaping students' inclusive religious behavior and the implications of CBDC policies in shaping student-inclusive religious behavior. In addition, the significance of the difference lies in the research setting. In this case the research is more focused on Bina Nusantara University, Jakarta, which has students with different backgrounds of religious understanding. This is 
what distinguishes this study from previous studies. Studies like this are very important to carry out in an effort to improve the harmony of life for religious people not only to be passive (tolerant), but also to become harmony that has a dynamic face, is able to work together, and behaves inclusively in religion.

\section{Inclusive Religious Behavior Behavior}

In the Big Indonesian Dictionary (KBBI, 2004: 137), the word "behavior" means the response or reaction of a person (individual) to stimuli or the environment. Skiner in Notoatmodjo (2007: 133) said that behavior is a person's reaction to external stimuli. From a biological perspective, behavior is an activity of the organism or living creature concerned. Thus, human behavior is a human action or activity that has a very wide expanse. While Tulus (2004: 63) said that behavior is the result of the teaching and learning process that occurs as a result of his interaction with the surrounding environment caused by personal experiences.

According to Sarwono (1991: 26), every behavior that exists in humans is influenced by its development and growth. He further said that three things can be distinguished in the development of humans or other creatures, namely the maturation process, the learning process, and the innate or talent process.

Azwar (2002: 9) explained that behavior as a reaction is simple or complex and is an expression of a person's attitude. This attitude has formed within him due to pressure or obstacles, both from outside and from within him. This means that the potential reactions that have formed within him will appear in the form of actual behavior as a reflection of his attitude. So, it is clear that behavior is influenced, both by internal factors and environmental factors around them.

While Tulus (2002: 63) said that behavior is all human activities or activities, either directly observed or observable by outsiders. He emphasized that behavior is a concrete reflection that appears in attitudes, actions, and words that arise because of the learning process, stimuli, and the environment.
According to Notoadmodjo (2001: 175), specific attitudes that can influence behavior are social attitudes which are expressed by repetitively in the same activities or commonly called habits. The motive is the impulse, desire, and desire that comes from within. Values are subjective norms, while the driving force and holding force are advice or counseling and information. He added that attitudes influence behavior through a thorough and reasoned decision-making process. The impact of this is (1) behavior is not much determined by general attitudes, but by specific attitudes towards something, (2) behavior is influenced not only by attitudes but also by subjective norms, namely one's beliefs about what other people want for someone. do, and (3) attitudes towards a behavior along with subjective norms to form an intention or intention to behave in a certain way.

Based on the description above, it can be concluded that behavior is any human action or reaction caused by the drive of a concrete organism which can be seen from the habits, motives, values, driving force, and holding force as a reaction or response of a person that arises because of the experience of the learning process. and stimuli from the environment. The indicators are the response to the environment, the results of the teaching and learning process, concrete expressions in the form of attitudes, words and actions.

\section{Inclusive}

According to Eliade (1959: 89), inclusive means up to or including. This term is used to indicate a state or behavior that views other groups as part of or included in that state. In addition, this term is also used to indicate that something that is owned by someone may also exist in other people, or the truth that is owned by a religion, may also exist in other religions. So, the essence of inclusion is the desire to understand each other, understand each other, and give each other between one group and another. An inclusivist does not allow himself to be dominated or enslaved by one particular understanding, teaching, belief/religion. For him, claims of truth and claims of salvation do not constitute the monopoly of certain groups or religions, but also exist in other groups or religions. Inclusivism refers to a person's religious attitudes and views that outside the religion he adheres to, there is also truth even though it is not as complete or perfect as the religion he adopts. 
According to Flood (2013: 78), an inclusive attitude tends to reinterpret things in such a way that they are not only suitable, but also acceptable. Such an attitude will lead to universalism. A doctrinal truth can hardly be accepted as universal if it too insists on retaining its specific content because the perception of content always presupposes the need for a special 'forma mentis'. Conversely, a tolerant acceptance of the existence of different levels will be easier to achieve. Meanwhile, an umbrella pattern or formal structure can easily embrace different systems of thought.

According to Hidayat, (2003: 45), every religion teaches people to love one another, to help as a form of devotion and love for God. The main obstacle to the development of open behavior and respect for other religions is the arrogance of truth or exclusion of people from other religions. It happens because the language is "I am here, while you are there", not us. This means that exclusively religious behavior (fanaticism, fundamentalism, extremism, religious radicalism) makes a person closed off and at a distance from others.

To realize this inclusive religious behavior, according to Benawa (2016), three basic principles are needed. First, frank witness, which means that each party does not hide their beliefs to eliminate suspicions or fears that are not expressed. Second, mutual respect, which means sympathetic behavior towards other people's difficulties and respect for other people's achievements. Third, religious freedom, that is, there must be recognition of the right to embrace religion without coercion.

Based on the description above, it can be concluded that religious inclusive behavior is any action or reaction that can be seen from the habits, motives, and values in humans who view that other religions are part of themselves or the truth that is owned by a religion may also exist. in another religion. The indicator is the response of religious people in the form of attitudes, words, and actions that open up to diversity in dealing with humans of other religions around them.

\section{METHOD}

This study uses a qualitative method. According to Polit \& Beck (2012), qualitative research is a research procedure that produces descriptive data in the form of words or writings from people and observed behavior. This research is an in-depth investigation of a matter in order to obtain rich descriptive information and to analyze the relationships that occur in it related to the phenomenon under study.

The focus of this research is to understand why a person or group of students thinks to build a religiously inclusive behavior towards the actions taken in the learning process of the Religion CB in Binus. This study uses various data sources, such as data on results from focus group discussions (FGD), participant observation, and documents.

Furthermore, the researcher developed a simple research instrument in the form of a number of questions to conduct FGDs and interviews with several informants. In this case, writing instruments, cell-phones are recording devices when conducting interviews and FGDs. On the other hand, observations are carried out using observation guidelines and digital cameras to record any activity related to the problem being studied, namely religious inclusive behavior in Binus.

\section{RESULTS AND DISCUSSION \\ RESULTS}

Bina Nusantara University Jakarta Community (hereinafter abbreviated as Binus). Binus in academic development has established the Character Building Development Center (CBDC) since 2001. CBDC is tasked with planning and developing teaching methods, creating training, and developing skills for lecturers and students. Character education is integrated into all university education programs, including comprehensive college programs that aim to build alumni who are not only smart and skilled, but also have strong character and good personality. According to Triguna, (2015: 50) in Hinduism it is called pradnyan. That is, mastering competences in accordance with their fields and virtuous purusotama.

CBDC Binus has the responsibility of developing materials and preparation for character education 
for all Binusians (Binus students). Binus through the $\mathrm{CB}$ Religion lecture wants to improve the quality of inclusive religious life with targets, namely self-management as well as teamwork skills that lead to maturity in religion and belief. According to Antonius Gea (2018), soft skills development-based activities through group discussions, presentations, and questions and answers are some of the ways to build active and creative religious inclusive behavior. The impact of the learning process through teamwork activities inside and outside the classroom greatly builds and improves student soft skills so that there is harmony between students of different religions. The expected impact is that the binusians are able to apply soft skills of teamwork in a pluralistic work environment and social environment.

\section{Theoretic Results}

The theoretical findings in this study are in the form of statements or propositions, both which strengthen the theoretical structure used and confirm the implications of the theory. The theoretical findings in this study can be explained as follows.

1. Binus is a university that has a relatively large number of students and consists of students of various religions. The harmony of religious life in Binus is supported by the personal awareness and communal awareness of students to create harmony in living together. This awareness is manifested in students' inclusive religious behavior, both personally and communally in their lives. Alfred Schutz's phenomenological approach helps students express themselves naturally. Through the FGD, students shared all kinds of dimensions of their experiences related to the application of inclusive religious behavior in their lives. With their awareness, students interpret their experiences in building relationships between religious believers around them. In other words, the phenomenologist Alfred Schutz has explored the deepest awareness of students in interpreting their personal experiences, especially in implementing inclusive religious behavior in their lives, especially in life within the family, on campus, and in the community. Through Alfred Schutz's phenomenological approach, it can also be proven that an objective meaning of the need for inclusive behavior to occur is actually connected with experiences in relationships with other people. In this case it does not only have an individual meaning, but also has a collective meaning.

2. A student is said to be more inclusive in religion, not only because he has a lot of religious knowledge, but also because he has inclusive behavior which is manifested in concrete life. Likewise, when students apply religiously inclusive behavior through project assignments outside the classroom, within the family, and in society, a student increasingly shows the quality of inclusiveness in religion. This finding supports the social construction theory of Peter L. Berger and Thomas Luckmann which states that humans construct social reality through subjective and objective processes. The construction process occurs through habituation and internalization of individuals in living together.

3. Understanding and implementing the inclusive religious behavior of Binus students has implications for an atmosphere of harmony between religious communities in the Binus academic community. The harmonious atmosphere that is manifested is the result of the interpretation and acceptance of students, both individually and socially, towards the inculcation of inclusive religious behavior by Binus through Character Building Development Center (CBDC). Planting through learning inside and outside the classroom has implications for the harmony of the religious life of the academic community in Binus. This finding supports Stuart Hall's reception theory, especially regarding the individual's meaning of social texts. A social text becomes more meaningful when more people accept and interpret it (dominant hegemonic position).

\section{Practical Results}

Practically the findings of this study can be stated that the religious inclusion behavior in Binus is well implemented by Binus students. This research has practical implications for the realization of harmonious relations between religious believers in Binus. Higher education institutions are pilot projects for the progress and greatness of the 
nation. Indonesian society that is already saturated with religious conflicts that often occur can be responded to by concrete efforts by higher education institutions, such as the development of this inclusive religious behavior. Furthermore, it can be explained as follows.

1. The harmonious relationship between students has been actualized in the life of the academic community at Binus. This is reflected in the harmony and togetherness that occurs, both inside and outside the classroom. This harmony does not only occur in the Binus environment, but also occurs in relations with the wider community. Inclusive religious behavior is manifested through social activities by students, both those involved in spiritual UKMs and student associations in Binus.

2. The inclusive religious behavior applied by Binus students in life is an ability that needs to be nurtured and developed. In the world of work, students will meet individuals who may be different, be it religion, ethnicity or race. The inculcation of inclusive religious behavior has become a habituation before they enter the world of work. The application of inclusive religious behavior is one form of individual social intelligence (sociability) in relating to other people around him.

3. The inclusion of inclusive religious behavior among students by Binus has been well-planned and planned. Good planning and planting in students will produce useful fruits for the community. The more well planned (the learning process, the assessment system, technical activities, etc.), the religious pluralism of students at Binus will increase significantly.

4. The development of inclusive religious behavior through Binus is gaining momentum because the symptoms of national disintegration are getting stronger along with the introduction of regional autonomy. The challenges of religious radicalism and exclusivism also need to be countered by cultivating inclusive religious behavior. In this case, higher education institutions are one of the important pillars to participate in overcoming these problems towards a more civilized and dignified Indonesia.

\section{DISCUSSION}

Compared to research conducted by Bahari (2010), this study showed that the most dominant variable has a direct effect on student religious tolerance in tertiary institutions, namely the educational environment variable in the family environment, school environment, and community environment. The social environment is very influential on the formation of religious tolerance attitudes. In contrast to Bahari's research, this study showed that how religious CB (Character Building) learning in Binus can build religious-inclusive behavior among students.

The significance of the difference between this study and the research conducted by Lukman (2011) lied in the research setting. In this case, research in Binus has students with different backgrounds in understanding religion, culture, ethnicity, and race. This research has shown that the formation of inclusive behavior in Binus can be realized in cooperation with many parties. This research also showed how the influence of lecturers, educational staff, and institutions in a wider area is very influential on the formation of inclusive religious behavior of students in Binus.

Meanwhile, compared to research conducted by Burhanudin (2014), this research has explored how CB Religion courses given to Binus students can build opinions about inclusive behavior in religion. It is proven that the process of forming religiously inclusive behavior can be carried out through the social construction pursued by Binus through CBDC. It has been proven from this research that the construction of CB Religion values internalized by Binus students as a natural attitude will be deposited in their memory through religious activities and activities, especially through social project assignments outside the classroom. The inculcation of these values has built a religiously inclusive attitude among Binus students.

Compared to the research conducted by Sofyan (2011), there are significant differences in terms of the object of research. Sofyan emphasizes more on the word "religious tolerance", while this research focuses more on "inclusive behavior" in religion, especially on the process of forming inclusive religious behavior among students at Binus. 
Meanwhile, research on the concept of religious tolerance has been conducted by Fatah (2015) concluded that the Pendidikan Agama Islam (PAI) learning process with a case study at SMA Negeri 1 Kota Tangerang Selatan has proven to be able to build a culture of religious tolerance among school members. The results of this study indicated several ways that can be done to instill the values of religious tolerance in students, namely student-centered learning approaches, learning methods based on religious tolerance, and extracurricular activities based on religious tolerance. These findings provided confirmation that tolerance can be formed through cognitive studies. Meanwhile, the findings of this study indicated that student project assignments outside the classroom can shape inclusive religious behavior among Binus students.

Meanwhile, Darmani's research (2012) stated that tolerant behavior needs to be practiced in various arts of life, namely family life, school life, society, as well as nation and state. This finding confirmed the findings of this study that tolerance can be used as an alternative bridge towards togetherness for the sake of national unity and unity in plural and diverse situations. Binus, who is plural and has not only a religion, has been able to create unity and integrity. The findings were obtained in the practical project assignments outside the student classroom in the context of building inclusive behaviors in religion.

Study which conducted by Ghazali (2011) showed that in line with the Islamic doctrine of religious harmony, it is necessary to develop PAI subjects with the insight of religious harmony. This is important because Islamic religious education must adapt to the community environment and be forward oriented. In addition, educational practice must be in accordance with the development of society and educational theories. On the other hand, educational theories must come from the perspective of life of the community concerned. The format of the PAI (Islamic Education) curriculum material with the insight of religious harmony for public high schools can help policy holders and education managers in developing multi-religious and multicultural-based PAI curricula.

Ghazali's research results confirmed the findings of this study on how to structure religious education based on multiculturalism and the extent to which CB Religion learning initiated by CBDC has implications for the development of inclusive behavior among Binus students.

The research which conducted by Mahyuddin (2020) showed the role of the Ambon State Islamic Institute (IAIN) and the Ambon State Christian Institute (IAKN) in maintaining social tolerance and religious moderation. The results of this study indicated that the consequences of past religious conflicts affect social tolerance and religious moderation in society. However, this threat can be resolved by the two religious higher education institutions by providing assistance and guidance to the wider community on the importance of maintaining harmony in diversity. In an effort to break down differences and antagonisms in society, Ambonese society is increasingly open, can become "living harmony" and out of the world of "suspicion and hostility" even though the relationship between religious groups still has a strong potential for recurring social friction involving two religious groups. Mahyuddin's findings provided confirmation of the results of this study on how good guidance and assistance to the community by high-ranking religious institutions is able to bridge existing conflicts even though they are not completely resolved, for example through planting the values of the Religious Character Building which have implications for interreligious harmony among the Binus students.

Research which conducted by Abdul Aziz (2020) showed that pluralist educational methods in Islamic religious education have positive implications for the relations between religious believers at the Curub State Islamic Institute. These findings confirmed the results of this research that religious education that is pluralist in nature will have an impact on the harmony of life between religious believers through a pluralist religious learning method and which not only emphasizes the cognitive side, but also fosters the affective and psychomotor sides, even up to the application of inclusive behavior in religion in Binus University. Research which conducted by Setara Institute (2018) concluded that social capital for youth 
tolerance is very strong, but social capital is underdeveloped and confined. This is because the state administrators, including political parties, do not function properly. This finding confirmed the results of this research that it is not enough only students who have an inclusive spirit in religion. Therefore, it is necessary to be supported by the administrators of the education system in the formation of a religiously inclusive attitude among Binus students.

In short, compared to previous studies, this study has a specificity in terms of the focus of the study which is more directed at how the learning of $\mathrm{CB}$ Religion in Binus forms inclusive student religious behavior and what the implications of CBDC policy are in shaping students' inclusive religious behavior. In addition, the significance of the difference lies in the research setting. In this case the research is more focused on Bina Nusantara University, Jakarta, which has students with different backgrounds of religious understanding. The results of this study can be used to improve the harmony of religious life which is not only passive (tolerant), but also a harmony that has a dynamic face, is able to work together, and behaves inclusively in religion.

\section{CONCLUSION}

Based on the result and discussion of the inclusive religious behavior of students at Binus, several things can be concluded as follows.

1. Inclusive religious behavior is a behavior that is needed by students in building relationships between individuals in the academic community in Binus. At the level of the religious knowledge dimension, experience dimension, and the virtue of values dimension of Binus students, it appears that inclusive religious behavior is needed to establish harmonious relationships between students, especially in an effort to ward off various streams of exclusivism and religious radicalism which is not impossible to enter the academic community in Binus.
2. The quality of the development of inclusive religious behavior for Binus students is well embedded, especially in the aspects of the quality of developing understanding and the quality of implementing religiously inclusive behavior. This is strongly supported by the development of the Religion Character Building (CB) course driven by the Binus Character Building Development Center (CBDC). Various learning models in the classroom and outside the classroom through CB Religion have instilled the values of inclusive religious behavior among Binus students, especially within the family, in the classroom community, and in society.

At least there are two reasons why that diversity should be accepted and treated with a good moral attitude.

First, an organization or group open to difference is far more competitive than a closed organization or group of differences.

Second, the more ethical and sociological reasons, that is, only by recognizing that diversity of identity as a unique individual becomes firm and clear. The uniqueness of a person will never be realized if he has never been in diversity. Thus, diversity is a gift that must be accepted by every human being.

Therefore, if someone rejects such diversity or treats diversity with an unkind moral attitude, he/she indirectly denies the nature of him/her-self as a human being.

\section{IMPLICATION}

The quality of inculcating religious inclusive behavior of Binus students that goes well has implications for the life of Bina Nusantara University Jakarta.

First, the relations between students of different religions in the classroom are getting tighter.

Second, creating a family atmosphere between students in the organization.

Third, the lecture atmosphere is conducive in the classroom.

Fourth, Binus' closeness to the surrounding community.

Fifth, the brotherhood of the Binus academic community is getting tighter. 
Sixth, Binus' achievement enhancement, both on a national and international scale.

\section{REFERENCE}

Aziz, Abdul (Ed.). 2011. Pandangan Pemuka Agama tentang Eksklusivisme Beragama di Indonesia, Jakarta: Puslitbang Kehidupan Keagamaan Badan Litbang dan Diklat Kementerian Agama RI.

-----.. 2020. "Implementasi Metode

Pendidikan Pluralisme dalam

Pendidikan Agama Islam". Jurnal Pendidikan Islam, 11(3).

Azwar, Saifudin. 2002. Sikap Manusia-Teori dan Pengukurannya. Yogyakarta: Pustaka Pelajar.

Bahari. 2010. "Pengaruh Kepribadian, Keterlibatan Organisasi, Hasil Belajar Pendidikan Agama, dan Lingkungan Pendidikan terhadap Toleransi Mahasiswa Berbeda Agama pada 7 Perguruan Tinggi Umum Negeri”. Disertasi. Jakarta: Badan Litbang dan Diklat Puslitbang Kehidupan Keagamaan.

Benawa, Arcadius. 2016. Iman Tiga Dimensi, Jakarta: Hegel Pustaka.

Burhanuddin. 2014. Konstruksi Sosial Media Massa: Kekuatan Pengaruh Media Massa, Iklan Televisi dan Keputusan Konsumen serta Kritik terhadap Peter L.Berger dan Thomas Luckmann. Jakarta: Kencana.

Gea, Antonius, et.al. 2018. Character Building Agama, Jakarta: Binus University.

Darmani, 2012. Toleransi Sebuah Jalan Ke Luar Pemersatu Anak Bangsa, Surabaya: Widyaiswara Madya Balai Diklat Keagamaan Surabaya.

Eliade, Mircea. 1959. The Sacred and The Profan, New York. Oxford University Press.

Fatah, Abdul. 2012. "Budaya Toleransi dalam Pembelajaran PAI", Tesis, Jakarta: UIN Syarif Hidayatullah.

Flood, Gavin. 2013. Beyond PhenomenologyRethinking The Study of Religion, London: Bloomsbury Academic.
Ghazali. 2011. Pendidikan Agama Islam Berwawasan Kerukunan Umat Beragama Sebuah Studi tentang Materi Kurikulum Pendidikan Agama Islam pada Sekolah Menengah Umum Negeri. Jurnal UIN Sunan Gunung Djati, Bandung.

Hidayat, Komaruddin. 2003. Menafsirkan Kehendak Tuhan, Bandung: Mizan.

Lukman. 2011. Model Pendidikan Toleransi antar Umat Beragama melalui Pembelajaran Agama Islam, Studi Kasus di SMA Negeri 1 Kota Tasikmalaya. Terbitan???

Mahyuddin. (2020). Peran Strategis IAIN Ambon dan IAKN Ambon dalam Merawat Toleransi Sosial dan Moderasi Beragama di Ambon Maluku, Jurnal KURIOSITAS, 103-124.

Maksum, Ali. 2011. Pluralisme dan Multikulturalisme; Paradigma Baru Pendidikan Islam di Indonesia, Malang: Aditya Media Publishing.

Notoatmodjo, Soekidjo. 2003. Pendidikan dan Perilaku Kesehatan, Jakarta: Rineka Cipta.

Peter L Berger dan Thomas Luckman. 1991. Tafsir Sosial atas Kenyataan, Jakarta: LP3ES.

Polit, Denise F., \& Beck, Cheryl T. 2012. Nursing research: generating and assessing evidence for nursing practice, Philadelphia: Lippincott Williams \& Wilkins.

Sarwono, Sarlito Wirawan. 1991. Pengantar Ilmu Psikologi, Jakarta: PT Bulan Bintang.

Schutz, Alfred. 1967. The Phenomenology of the Social World. Illinois: Northon University Press.

Setara Institute, Wacana dan Gerakan Keagamaan di Kalangan Mahasiswa: Memetakan Ancaman atas Negara Pancasila di Perguruan Tinggi Negeri, 31 Mei 2019.

Shihab, Alwi. 2005. Islam Inklusif, Jakarta: Taraju Press.

Sofyan. 2011. Persepsi Mahasiswa terhadap Kata Toleransi Kehidupan Beragama. Jurnal Penelitian Humaniora UMS Vol. 12, No. 2.

Susanto, Edy. (2006). Pendidkan Agama Berbasis Multikultural. Jurnal Sosial dan Budaya Karsa, 11(1).

Triguna, Ida Bagus Gde Yudha. 2011. Strategi Hindu. Jakarta: Pustaka Jurnal Keluarga. -2011. Budaya Inspiratif \& Pembangunan Karakter. Tabanan: Pustaka Ekspresi Bekerja sama 
dengan Pascasarjana Universitas

Hindu Indonesia.

(2015).

Pembangunan Kharakter dan

Pembangunan Diri menurut Perspektif Agama Hindu, Dharmasmarti, 8 (2).

Tulus. 2004. Peran Disiplin pada Perilaku dan Prestasi Belajar. Jakarta: Grasindo Widiasarana.

Utama, I Wayan Budi. (2018). Filasat Pendidikan Menurut Pemikir Hindu. Dharmasmarti, 9 (2), 86-90.

Fenomena Kegilaan. WIDYA WRETTA, 1 (1), 107-115. 